\title{
STRATEGI PENGEMBANGAN USAHA PRODUKSI TEMPURA IKAN PADA SKALA USAHA RUMAH TANGGA (STUDI KASUS TEMPURA IKAN X KOTA DENPASAR, BALI)
}

\author{
Nur Zaenab Mentari Wirawan ${ }^{1}$, A.A.P. Agung Suryawan Wiranatha. ${ }^{2}$, Amna Hartiati ${ }^{2}$ \\ ${ }^{1}$ Mahasiswa Jurusan Teknologi Industri Pertanian, Fakultas Teknologi Pertanian Unud \\ ${ }^{2}$ Dosen Jurusan Teknologi Industri Pertanian, Fakultas Teknologi Pertanian Unud \\ Email: nurzaenab73@yahoo.co.id ${ }^{1}$ \\ Email koresponden: agung_suryawan@unud.ac.id²
}

\begin{abstract}
The objectives of this study were to analyze the internal and external conditions, formulate the strategy and determine the priority strategy for business development of Tempura Fish X. Analysis of business development strategies was using a matrix SWOT (Strengths, Weakneses, Oppurtunities, and Threats), Quantitative analysis using EFE, IFE and IE matrix, and strategy priority analysis was using TOPSIS (Technique for Order of Preference by Similarity to Ideal Solution. The results show that there are 5 strengths, 5 weaknesses, 4 opportunities and 2 threats. The IFE matrix analysis value (Internal Factor Evaluation) is 2.96 and the EFE (External Factor Evaluation) matrix is 3,006. The value indicates a moderate position on the IE matrix (Internal External). The strategy proposed are to develop a strategy consisting of intensive strategy (market penetration, market development, and product development), and integrative strategies (backward integration, forward integration and horizontal integration). Based on SWOT analysis there are 8 alternative strategies that can be recommended to development Tempura fish X business. TOPSIS analysis results with the value of the proximity of each alternative to the ideal solution is 1,00 namely expand the market by selling products to small restaurants, school cafeteria, and also food stalls
\end{abstract}

Keywords: Business development strategy, tempura fish, SWOT, TOPSIS

\section{PENDAHULUAN}

Manufaktur makanan merupakan industri yang paling berkembang dan dikembangkan di dunia (Mehrotra dkk, 2011). Salah satu industri makanan adalah usaha tempura ikan X disamping makanan lain seperti siomay ikan, nugget ikan, dan bakso ikan. Tempura berasal dari bahasa Portugis temporas (masa suci), tempero (bumbu dapur), templo (kuil), atau tempora yang berasal dari bahasa Spanyol atau bahasa Italia. Tempura biasanya terbuat dari beragam bahan, seperti udang, fillet ikan dan juga beragam sayuran seperti bawang bombay, paprika, terung, jamur, wortel, ubi dan yang lainnya. Tempura yang biasa dibuat di kalangan masyarakat menggunakan tepung tempura yang sudah tercampur dengan tepung terigu dan bubuk telur. Tepung tempura mengandung bahan-bahan seperti soda kue dan bahan pengembang seperti baking powder agar hasil gorengan menjadi garing dan tidak keras. Tempura merupakan makanan ringan yang gurih, sehat dan mengenyangkan. Pada umumnya suhu minyak menggoreng tempura berkisar $160^{\circ} \mathrm{C}-$ $170^{\circ} \mathrm{C}$. Suhu yang rendah digunakan untuk menggoreng sayur-sayuran dan makanan laut seperti kerang, karena kerang mudah menjadi keras saat suhu tinggi. Suhu tinggi digunakan untuk menggoreng udang, cumi-cumi, dan ikan.

Ikan merupakan salah satu bahan pangan yang mempunyai manfaat dalam bidang kesehatan dengan kandungan gizinya yang tinggi. Kandungan gizi utama pada ikan adalah proteinnya yang mudah dicerna dan kandungan asam lemak tidak jenuhnya berupa Eicosa Pentaenoic Acid (EPA) dan Docosa Hexaenoic Acid (DHA) sangat berperan penting dibidang kesehatan. Adapun mutu dan kandungan gizi yang ada pada ikan 
tersebut sangat tergantung dari cara penangkapan dan penanganan selama transportasi sampai ke tangan konsumen. Menurut Martosubroto, dkk (1991) ikan tenggiri digemari oleh masyarakat karena rasa dagingnya yang gurih dan tidak amis bila dibandingkan dengan jenis ikan lainnya. Ikan tenggiri banyak ditemukan di perairan Indonesia seperti di pantai utara Jawa, pantai selatan Jawa Tengah, pantai utara dan selatan Bali, Sumatera, Kalimantan, Sulawesi, Nusa Tenggara, Maluku, dan Irian Jaya.

Persaingan antar kompetitor khususnya di daerah Kota Denpasar menjadi suatu tantangan tersendiri bagi Perusahaan X untuk mampu mempertahankan dan mengembangkan usahanya. Proses produksi tempura ikan Perusahaan X masih menggunakan teknologi sederhana. Indikasi permasalahan yang dihadapi usaha tempura ikan di tengah situasi persaingan yang sangat ketat menunjukkan bahwa usaha tempura ikan memerlukan langkah-langkah strategis untuk dapat mengembangkan usaha agar meningkatkan omzet penjualan perusahaan. Oleh karena itu, perlu dilakukan analisis faktor internal dan eksternal untuk mengetahui kekuatan dan kelemahan, serta dapat memanfaatkan peluang dan mewaspadai ancaman yang dihadapi agar dapat menjadikan produk tersebut berkembang pesat. Tujuan penelitian ini adalah menganalisis faktor lingkungan internal dan eksternal yang dihadapi oleh produksi tempura ikan Perusahaan $\mathrm{X}$ dan merumuskan strategi dan menetapkan prioritas strategi pengembangan usaha tempura ikan X.

\section{METODE PENELITIAN}

\section{Tempat dan Waktu Penelitian}

Penelitian ini dilaksanakan di usaha tempura ikan Perusahaan X Denpasar Selatan pada bulan November 2017.

\section{Tahapan Penelitian}

Penelitian ini dilakukan melalui survei, obervasi lapangan, wawancara dan pencatatan data studi pustaka. Data yang digunakan dalam penelitian ini adalah data primer dan data sekunder. Data primer diperoleh melalui wawancara, observasi lapangan dan data hasil kuesioner. Data sekunder diperoleh meliputi sumber informasi berupa laporan penelitian teknologi pertanian. Selain itu data sekunder diperoleh melalui studi literatur buku-buku yang relevan dan juga artikel yang terkait dengan topik penelitian. Data tersebut diperoleh dari perusahaan, Dinas Perindustrian dan Perdagangan (Disperindag). Metode pengumpulan data yang digunakan dalam penelitian ini menggunakan teknik wawancara mendalam (depth-interview), dengan mengajukan tanya jawab secara terbuka dengan responden tentang permasalahan objek yang diteliti. Materi wawancara terdiri dari 4 kuisioner. Kuisoner satu (Lampiran 1) untuk mengetahui gambaran umum tempat usaha tempura ikan X Pimpinan Perusahaan. Kuisoner kedua (Lampiran 2) berisi pertanyaan tentang gambaran Kekuatan, Kelemahan, Peluang dan Ancaman yang dihadapi tempura ikan X. Kuisoner ketiga (Lampiran 3) untuk penentuan bobot faktor internal dan eksternal tempura ikan, sedangkan untuk kuisioner keempat (lampiran 4) penentuan rating faktor internal dan eksternal tempura ikan. Kuisoner kedua, ketiga, dan keempat akan diisi oleh para responden ahli. Tahapan penelitian ini dapat dilihat pada Gambar 1. 


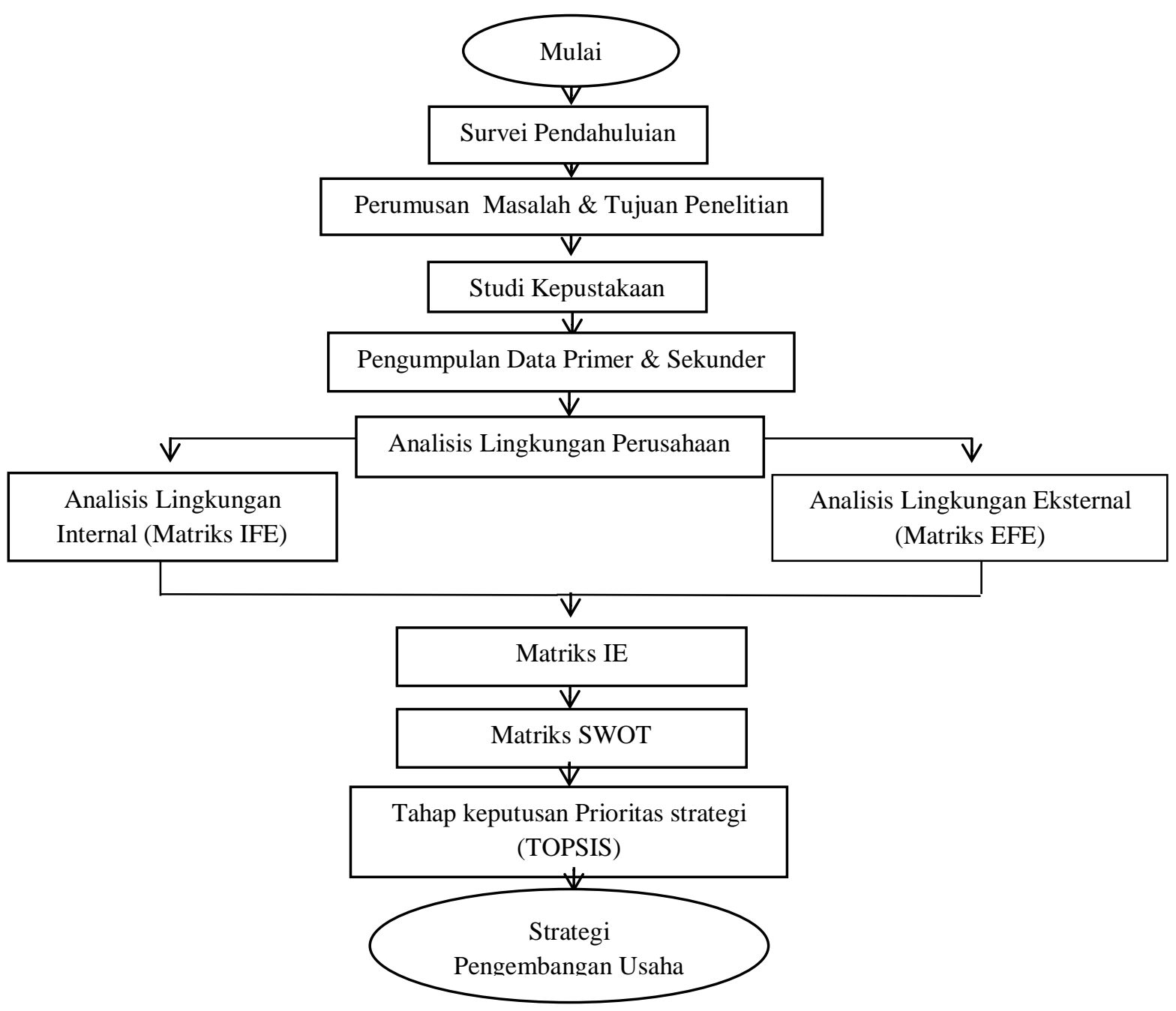

Gambar 1. Diagram alir Tahapan Penelitian

\section{HASIL DAN PEMBAHASAN}

\section{Gambaran Umum Perusahaan X}

Perusahaan X merupakan suatu usaha industri dengan skala rumah tangga yang berdiri sejak tahun 2004. Usaha ini didirikan oleh Bapak Awan Cahya dan Ibu Luh Cahya. Perusahaan X memproduksi beberapa produk yaitu bakso ikan, bakso ayam, bakso sapi, siomay, dan tempura ikan. Perusahaan X berkemampuan memproduksi tempura ikan 150 - $300 \mathrm{~kg}$ perbulan dan pada proses produksinya masih menggunakan alat yang sederhana yaitu wajan penggorengan, panci perebusan, mesin penggiling adonan, alat press dan alat pembeku (freezer).

\section{Analisis Lingkungan Perusahaan}

Menurut Glueck (1988) analisis lingkungan perusahaan merupakan suatu proses yang digunakan oleh pembuat strategi untuk memantau sektor lingkungan baik eksternal maupun internal untuk menentukan peluang dan ancaman terhadap perusahaan.

\section{Analisis Lingkungan Internal}

Menurut David (2009) semua organisasi mempunyai kekuatan dan kelemahan dalam berbagai bidang fungsional bisnis. Analisis lingkungan eksternal terhadap peluang dan ancaman tidak cukup untuk memberikan organisasi keuntungan kompetitif. Identifikasi faktor-faktor internal dilakukan dengan meninjau 
faktor-faktor yang terdapat pada perusahaan untuk mengetahui adanya kekuatan dan kelemahan perusahaan. Aspek-aspek internal tempura ikan X yakni produksi, pemasaran, keuangan, dan sumber daya manusia

\section{1) Produksi}

Proses produksi tempura ikan dengan menyiapkan bahan baku utama yaitu ikan tenggiri lalu ditambahkan dengan wortel, brokoli, tepung terigu, bengkuang, garam, gula dan air es. Ikan tenggiri dibersihkan dan difillet, lalu digiling agar ikan hancur. Tahap selanjutnya karena kurangnya tenaga ahli dalam mengolah tempura ikan secara baik maka adonan hanya dibentuk dengan ukuran telunjuk jari tanpa menggunakan mesin pencetak sehingga proses pembentukan adonan kadang tidak seragam dengan yang lain. Adonan yang sudah dibentuk direbus lalu digoreng setengah matang. Selanjutnya tempura ikan yang setengah matang dikemas dan ditimbang per $1 \mathrm{~kg}$ dan disimpan dialat pembeku(Freezer).

\section{2) Pemasaran}

Menurut Kotler dan Amstrong (1997) mengemukakan bahwa pendekatan pemasaran 4P yaitu product, price, place, dan promotion. Aspek yang sering dikenal tempura ikan bila dilihat dari bauran pemasaran yaitu aspek produk, aspek harga, aspek distribusi, aspek promosi.

a) Aspek Produk

Produk yang diproduksi oleh Perusahaan $\mathrm{X}$ adalah tempura ikan dengan bahan baku ikan tenggiri yang memilki cita rasa yang khas dan diolah untuk menjadi makanan yang sehat. Perusahaan tempura ikan $\mathrm{X}$ bebas bahan pengawet dalam proses produksinya. Pada kemasan produk tidak ada label halal, nama merk, dan tanggal kadaluarsa. Produk dikemas menggunakan mesin pengemas dan dipress dengan menggunakan plastik besar dengan ukuran $1 \mathrm{~kg}$, dan untuk 10kg menggunakan karung kampil.

b) Aspek Harga

Harga merupakan salah satu variabel yang harus dikendalikan secara benar, karena harga akan sangat berpengaruh terhadap beberapa aspek kegiatan perusahan, baik menyangkut kegiatan penjualan maupun aspek keuntungan yang ingin dicapai oleh perusahaan. Harga tempura ikan X adalah Rp. 35.000 per $1 \mathrm{~kg}$ dan Rp. 350.000 per $10 \mathrm{~kg}$.

c) Aspek Distribusi

Distribusi adalah salah satu aspek dari pemasaran. Distribusi juga dapat diartikan sebagai kegiatan pemasaran yang berusaha memperlancar dan mempermudah penyampaian barang dan jasa dari produsen kepada konsumen, sehingga penggunannya sesuai dengan yang diperlukan (jenis, jumlah, harga, tempat, dan saat dibutuhkan). Perusahaan X mendistribusikan produknya pertama kali melalui sampel produk yang dibagikan di sekitar area lingkungan rumah, rumah makan, restoran, dan orang-orang terdekat. Cara yang kedua Perusahaan X membuka tempat penjualan yang secara langsung di tempat produksi. Biasanya para konsumen yang ingin membeli produk langsung mendatangi ke tempat Perusahaan X. Sistem pembayaran untuk konsumen yang dilakukan oleh Perusahaan X secara tunai. Perusahaan X tidak memproduksi ke luar daerah jadi tidak terdapat biaya transfer pengiriman. 
d) Aspek Promosi

Promosi yang dilakukan Perusahaan X dengan cara word of mouth. Word of mouth merupakan suatu bentuk pemasaran dimana konsumen memegang kendali dan berpartisipasi sebagai pemasar untuk mempengaruhi dan mempercepat pesan pemasaran dari periklanan, dimana orang - orang yang memberikan informasi dan membuat rekomendasi jujur kepada orang lain tentang merek, produk barang atau jasa dan layanan (Hasan, 2010).

e) Aspek Keuangan

Keuangan Perusahaan X dipegang oleh direktur keuangan yang bertugas mendata arus kas keuangan, untuk mengetahui secara cepat kinerja keuangan perusahaan, hal ini bertujuan untuk mengevalusai situasi keuangan yang terjadi saat ini, serta memprediksi kondisi keuangan masa yang akan datang dan sumber modal usaha ini berasal dari modal pribadi.

\section{3) Sumber Daya Manusia}

Perekrutan Perusahaan X dilakukan secara sederhana dengan melakukan promosi pembukaan lowongan kerja melalui media sosial. Calon karyawan diwawancara langsung oleh koordinator divisi dan diseleksi sesuai dengan kriteria dan persyaratan yang diperlukan. Pelatihan kerja diberikan bertujuan agar setiap karyawan mengetahui dasar-dasar perusahaan dan pekerjaan yang akan dikerjakan.

\section{Analsis Lingkungan Eksternal}

Lingkungan eksternal perusahaan merupakan faktor-faktor di luar kendali perusahaan yang dapat mempengaruhi pilihan arah dan tindakan, struktur organisasi dan proses internal perusahaan serta mencakup sejumlah variable (peluang dan ancaman) yang berada diluar organisasi (David, 2009)

\section{1) Kompetitor}

Persaingan dalam dunia bisnis memasuki fase baru di mana persaingan menjadi semakin kompetitif. Perkembangan teknologi informasi menjadi salah satu faktor yang menyebabkan perubahan pada fase tersebut. Teknologi informasi membuat arus atau pergerakan informasi semakin cepat. Persaingan ini menuntut para pelaku bisnis menjadi lebih kreatif untuk melakukan inovasi dalam pemasarannya agar dapat terus bisa bersaing. Kompetitor juga mampu menghasilkan dan memasarkan produk serupa ataupun menawarkan produk subtitusi dengan manfaat yang relative sama. Perusahaan sejenis yang menjadi kompetitor tempura ikan Perusahaan X adalah Bakso Supra Dinasty.

\section{2) Pemasok}

Pemasok atau supplier merupakan mitra bisnis yang memegang peranan sangat penting dalam menjamin ketersediaan barang pasokan yang dibutuhkan oleh perusahaan. Tempura ikan Perusahaan X memiliki 1 supplier ikan tenggiri yang berasal dari pelabuhan benoa. Supplier pada waktu tertentu masih menaikkan harga bahan baku. Selain itu juga terdapat keterlambatan supplier dalam hal pengiriman bahan baku yang sering terjadi. Hal ini dapat menghambat proses produksi karena kurangnya ketersediaan bahan baku

\section{Identifikasi Faktor Internal dan Eksternal}


Berdasarkan hasil analisis lingkungan internal dan eksternal perusahaan diperoleh beberapa faktor lingkungan internal dan faktor lingkungan eksternal usaha Tempura Ikan X. Faktor-faktor internal dan eksternal dapat dilihat pada Tabel 1. dan Tabel 2.

Tabel 1. Faktor strategis internal

\begin{tabular}{|c|c|}
\hline Kekuatan & Kelemahan \\
\hline 1. Rasa Tempura Ikan lebih enak & 1. Kemasan kurang menarik \\
\hline $\begin{array}{l}\text { dibandingkan produk sejenis lainnya } \\
\text { 2. Harga lebih terjangkau dibandingkan } \\
\text { produk sejenis lainnya }\end{array}$ & $\begin{array}{l}\text { 2. Kurangnya keterampilan karyawan dalam } \\
\text { mengolah tempura ikan } \\
\text { 3. Warna produk kurang menarik }\end{array}$ \\
\hline 3. Bebas bahan pengawet & 4. Pemasaran kurang baik karena kurangnya \\
\hline $\begin{array}{l}\text { 4. Tempura Ikan mengandung protein yang } \\
\text { tinggi karena berbahan baku ikan tenggiri } \\
\text { 5. Bahan baku ikan tenggiri memiliki cita } \\
\text { rasa yang khas }\end{array}$ & $\begin{array}{l}\text { 5. Produk yang berbahan baku ikan cepat } \\
\text { tengik, dan rentan terkontaminasi oleh } \\
\text { mikroba }\end{array}$ \\
\hline
\end{tabular}

Tabel 2. Faktor strategis eksternal

\begin{tabular}{llll}
\hline \multicolumn{1}{c}{ Peluang } & \multicolumn{1}{c}{ Ancaman } \\
\hline 1. Adanya promosi pemerintah & 1. Kompetitor atau pesaing menghasilkan \\
tentang gerakan "ayo makan & 2. Harga bahan baku yang tidak stabil \\
$\begin{array}{l}\text { ikan" sebagai sumber protein. } \\
\text { 2. Masyarakat mulai menyukai tempura ikan }\end{array}$ & \\
3. Himbauan camilan sehat untuk anak-anak & & \\
4. Kebutuhan konsumen akan & & \\
& $\begin{array}{l} \\
\text { produk fungsional, berbentuk } \\
\text { produk siap jadi sehingga praktis }\end{array}$
\end{tabular}

\section{Tahap Input (Input Stage)}

Tahap input (Input Stage) yakni meringkas informasi dasar yang diperlukan untuk merumuskan suatu strategi. Alat input mengharuskan strategi untuk menghitung secara subyektif dalam tahap awal dari proses perumusan. Tahap ini menghasilkan faktor-faktor internal dan eksternal perusahaan. Alat analisis yang digunakan adalah IFE dan EFE.

\section{Analisis Matriks EFE dan IFE}

Analisis matriks EFE dan IFE dibuat berdasarkan hasil identifikasi kekuatan, kelemahan sebagai faktor internal, peluang dan ancaman sebagai faktor eksternal.

\section{Matriks Internal Factor Evaluation (IFE)}

Analisis matriks IFE dilakukan dengan mengolah faktor-faktor internal pada usaha tempura ikan Perusahaan $\mathrm{X}$ yang terdiri dari kekuatan dan kelemahan usaha. Kelemahan dan kekuatan tersebut diberi bobot, dan rating. Matriks IFE dapat dilihat pada Tabel 3.

Tempura ikan Perusahaan X memiliki 2 kekuatan utama yaitu bebas bahan pengawet dengan nilai 0,375 dan memiliki cita rasa yang khas dengan nilai 0,373. Kekuatan pertama dan kedua ini harus dipertahankan demi mendukung kemampuan perusahaan dalam mengelola pengembangan usaha. Faktor kelemahan utama pada produk adalah kemasan kurang menarik dan kurangnya tenaga ahli dalam mengolah tempura ikan dengan memiliki nilai sebesar 0,275. Namun secara keseluruhan total nilai terbobot dari Matriks IFE adalah sebesar 2,955 yang menunjukkan bahwa tempura ikan Perusahaan X mampu merespon faktor internal dengan memanfaatkan kekuatan yang dimiliki untuk menutupi kelemahan. 
Tabel 3. Matriks internal factor evaluation (IFE)

\begin{tabular}{|c|c|c|c|c|}
\hline No & Kekuatan & $\begin{array}{l}\text { Bobot } \\
\text { (a) }\end{array}$ & $\begin{array}{l}\text { Rating } \\
\text { (b) }\end{array}$ & $\begin{array}{c}\text { Nilai } \\
\mathbf{a x b}=\mathbf{c}\end{array}$ \\
\hline 1 & Rasa tempura ikan lebih enak dibandingkan produk sejenis lainnya & 0,110 & 2,8 & 0,309 \\
\hline 2 & Harga lebih terjangkau dibandingkan produk sejenis lainnya & 0,098 & 3,2 & 0,314 \\
\hline 3 & Bebas bahan pengawet & 0,110 & 3,4 & 0,375 \\
\hline 4 & $\begin{array}{l}\text { Tempura ikan mengandung protein yang tinggi karena berbahan baku } \\
\text { ikan tenggirir }\end{array}$ & 0,104 & 3,2 & 0,334 \\
\hline 5 & $\begin{array}{c}\text { Bahan baku ikan tenggiri memiliki cita rasa yang khas } \\
\text { Kelemahan }\end{array}$ & 0,098 & 3,8 & 0,373 \\
\hline 1 & Kemasan kurang menarik & 0,098 & 2,8 & 0,275 \\
\hline 2 & Kurangnya keterampilan karyawan dalam mengolah tempura ikan & 0,098 & 2,8 & 0,275 \\
\hline 3 & Warna produk kurang menarik & 0,117 & 2,6 & 0,303 \\
\hline 4 & Pemasaran kurang baik karena kurangnya promosi & 0,080 & 2,6 & 0,207 \\
\hline 5 & $\begin{array}{l}\text { Produk yang berbahan baku ikan memiliki cepat tengik dan rentan } \\
\text { terkontaminasi oleh mikroba }\end{array}$ & 0,086 & 2,2 & 0,189 \\
\hline & TOTAL IFE $(A+B)$ & 1,000 & & 2,955 \\
\hline
\end{tabular}

\section{Matriks External Factor Evaluation (EFE)}

Matriks EFE digunakan untuk menganalisis faktor-faktor eksternal perusahaan. Faktor-faktor eksternal yang telah diperoleh tersebut kemudian diklasifikasikan menjadi peluang dan ancaman yang dihadapi perusahaan. Matriks EFE dapat dilihat pada Tabel 4.

Tabel 4. Matriks external factor evaluation (EFE)

\begin{tabular}{|c|c|c|c|c|}
\hline No & Peluang & Bobot & Rating & $\begin{array}{l}\text { Nilai } \\
\mathbf{c}=\mathbf{a} \times \mathbf{x}\end{array}$ \\
\hline 1 & $\begin{array}{l}\text { Adanya promosi pemerintah tentang gerakan "ayo } \\
\text { makan ikan" sebagai sumber protein }\end{array}$ & 0,177 & 3,4 & 0,602 \\
\hline 2 & Masyarakat mulai menyukai tempura ikan & 0,167 & 3,2 & 0,533 \\
\hline 3 & Himbauan camilan sehat untuk anak-anak & 0,167 & 3,2 & 0,533 \\
\hline 4 & $\begin{array}{l}\text { Kebutuhan konsumen akan produk fungsional, } \\
\text { berbentuk produk siap jadi sehingga praktis }\end{array}$ & 0,167 & 3,2 & 0,533 \\
\hline 1 & $\begin{array}{l}\quad \text { Ancaman } \\
\text { Kompetitif atau pesaing yang menghasilkan produk } \\
\text { yang sejenis }\end{array}$ & 0,177 & 2,4 & 0,425 \\
\hline 2 & Harga bahan baku tidak stabil & 0,146 & 2,6 & 0,379 \\
\hline & TOTAL EFE $(A+B)$ & 1,000 & & 3,006 \\
\hline
\end{tabular}

Hasil dari matriks EFE menunjukkan peluang utama adanya promosi pemerintah tentang gerakan "ayo makan ikan" sebagai sumber protein dengan nilai 0,602 merupakan salah satu program untuk meningkatkan kesadaran terhadap konsumsi ikan. Ancaman utama yang dimiliki tempura ikan Perusahaan X adalah kompetitif atau pesaing yang menghasilkan produk yang sejenis dengan nilai sebesar 0,425 . Harga bahan baku yang tidak stabil membuat Perusahaan X sulit mengatasi, secara keseluruhan total nilai terbobot dari Matriks EFE adalah sebesar 3,006 yang menunjukkan bahwa tempura ikan Perusaahan X dapat memanfaatkan peluang yang ada dan mengatasi ancaman yang ada.

\section{Tahap Pencocokan (Matching Stage)}

Pada tahap pencocokan pengolahan data dilakukan dengan menggunakan matriks IE. Matriks ini diperoleh melalui penggabungan matriks IFE dan matriks EFE. Analisis ini merupakan tahap 2 yaitu 
pencocokan yang digunakan untuk mempermudah dalam memberikan pemilihan alternatif strategi. Berdasarkan pemetaan pada matriks IE dapat dilihat bahwa pada sumbu-x matriks IE nilai total IFE adalah 2,955, sedangkan pada sumbu-y matriks IE nilai total EFE adalah 3,006. Yang menunjukkan bahwa tempura ikan Perusahaan X terletak pada kuadran II.

Hasil analisis matriks IE dapat dilihat pada Gambar 2.

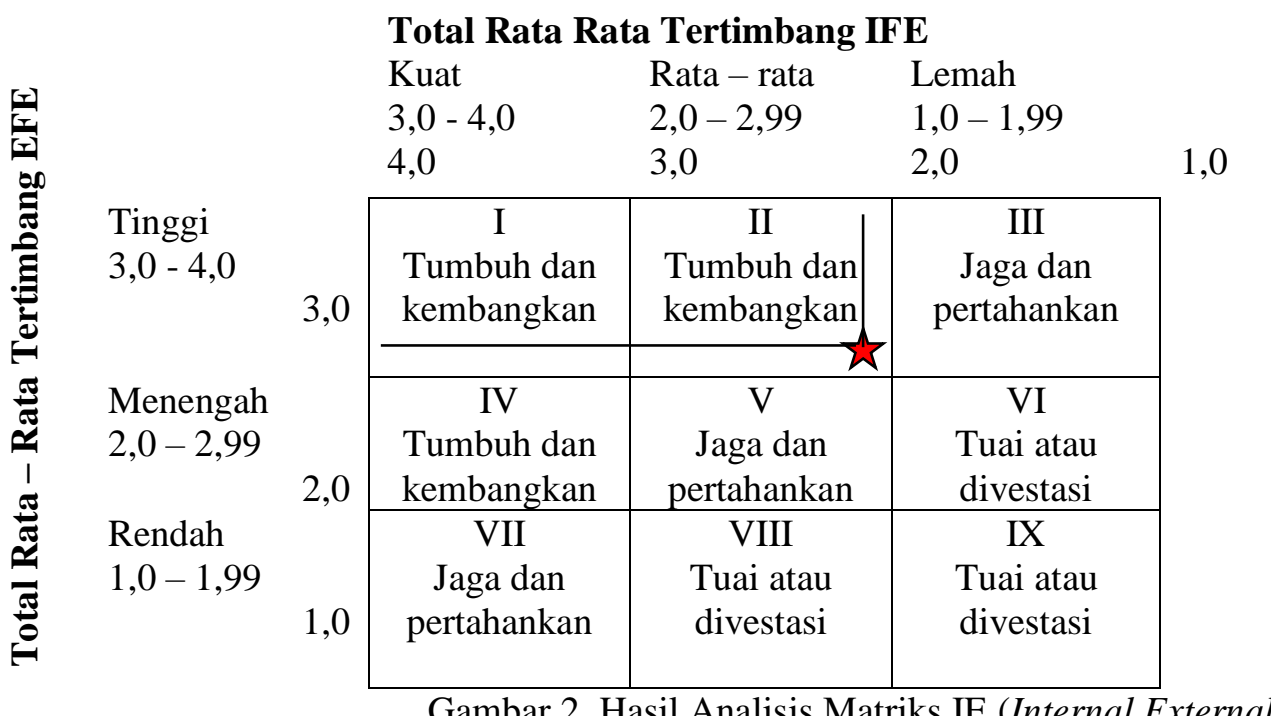

\section{Analisis Matriks SWOT}

Matriks SWOT merupakan alat pencocokan (matching tool) yang digunakan dalam mengidentifikasi berbagai faktor secara sistematis untuk merumuskan strategi perusahaan. Matriks ini menggambarkan bagaimana peluang dan ancaman eksternal yang dihadapi perusahaan dapat disesuaikan dengan kekuatan dan kelemahan yang dimilikinya. Berdasarkan analisis SWOT ada beberapa alternatife strategi yang dapat diterapkan perusahaan, yaitu :

\section{1) Strategi S - O (Strengths - Opportunities)}

Strategi ini menggunakan kekuatan internal perusahaan untuk memanfaatkan peluang eksternal. Strategi S-O bagi usaha tempura ikan Perusahaan X adalah:

a) Mempertahankan harga dan kualitas produk

Mempertahankan harga terjangkau dari produk sejenis yang lainnya, dan kualitas produk diperoleh dengan proses produksi melalui bahan baku utama tempura ikan adalah ikan tenggiri yang memiliki cita rasa yang khas rasanya yang enak dan dapat diolah menjadi produk setengah jadi atau siap jadi sehingga praktis dan bisa dijadikan camilan sehat untuk anak anak yang bebas bahan pengawet. Penggunaan bahan baku yang berasal dari ikan tenggiri inilah yang harus terus digunakan karena kandungan protein ikan tenggiri sangat tinggi Implementasi strategi ini diharapkan dapat menentukan persepsi konsumen mengenai kualitas produk tempura ikan Perusahaan X yang diharapkan.

b) Melakukan promosi dan sosialisasi kepada masyarakat secara berkala tentang manfaat gizi ikan sebagai kesehatan bagi tubuh manusia.

Melakukan promosi melalui media internet, dan mengadakan sosialisasi ke masyarakat agar mengerti betapa pentingnya mengkonsumsi ikan untuk pertumbuhan anak-anak. 


\section{2) Strategi S - T (Strengths - Treats)}

Strategi ini kekuatan internal perusahaan untuk menghindari atau mengurangi dampak ancaman eksternal. Strategi S-T bagi usaha tempura ikan Perusahaan X adalah:

a) Menjaga cita rasa produk yang khas agar tidak berubah dari tahun ke tahun

Tempura Ikan $\mathrm{X}$ harus melakukan hal-hal seperti tetap mempertahankan dan memperhatikan cita rasa dari produk, bebas bahan pengawet dan kekhasan dari produk tempura ikan yang dibuatnya untuk meningkatkan pelayanan kepada pelanggan dan menganggap kepuasan pelanggan adalah hal utama.

b) Melakukan pengelolaan persediaan bahan baku yang efisien dan efektif

Persediaan menurut Manullang (2005) merupakan jumlah bahan atau barang yang disediakan oleh perusahaan, baik itu merupakan barang jadi, barang dalam proses, maupun bahan mentah, untuk menjaga kelancaran proses produksi. Bahan baku adalah bahan utama atau bahan pokok dan merupakan komponen utma dari suatu produk. Bahan baku biasanya mudah ditelusuri dalam suatu produk dan harganya relatif tinggi dibandingkan dengan bahan pembantu. Persediaan bahan baku dalam perusahaan harus dikelola dengan baik, dimulai dengan baik mulai dari perencanaan sampai dengan pengendalian persediaan dan juga dimulai dari kegiatan pengadaannya sampai dengan penyampaiannya.

\section{3) Strategi W - O (Weaknesess - Opportunities)}

Strategi W-O adalah strategi yang menggunakan kelemahan perusahaan untuk menghindari dampak ancaman eksternal. Strategi S-T bagi usaha tempura ikan Perusahaan X adalah:

a) Memperluas pasar dengan cara menjualkan produk ke restoran kecil, kantin sekolah, dan juga warung makanan

Untuk Memperluas area pasar dan membuat perusahaan terus berkembang dengan menambah outletoutlet Tempura Ikan X, mengadakan sosialisasi tentang himbauan camilan yang sehat untuk anak-anak, melakukan kerjasama dengan sponsor-sponsor yang terkait dengan Tempura ikan, mengikuti kegiatan kepemerintahan tentang industri rumah tangga, dan menyebarkan beberapa brosur Tempura Ikan X agar lebih banyak diketahui kalangan masyarakat dan menjualkan produk ke warung, toko atau supermarket yang baru untuk memperluas pasar.

b) Melatih karyawan dengan cara memberikan pelatihan keterampilan dalam mengolah produk tempura ikan yang menarik dan praktis

Melihat kebutuhan konsumen di masa sekarang yang menginginkan produk siap jadi atau praktis. Produsen Tempura Ikan X harus memperhatikan tentang olahan produknya seperti kemasan yang harus menarik dengan mengisikan label halal, nama merk, tanggal kadaluwarsa, mesin pencetak adonan agar memiliki ukuran yang sama dengan yang lain dan bentuk yang diinginkan dan menjaga kualitas Tempura Ikan agar tidak cepat berlendir, dan terkontaminasi mikroba dengan cara memperhatikan pada saat pengemasan produk seperti sealer yang kuat agar tidak ada lubang udara yang keluar masuk dan suhu penyimpanan juga berpengaruh terhadap kualitas produk agar ketika sampai ditangan konsumen produk tidak mengalami perubahan suhu dan kecacatan produk. 


\section{4) Strategi W - T (Weakness - Threath)}

Strategi W-T adalah strategi yang menggunakan untuk mengurangi kelemahan internal dengan menghindari ancaman eksternal. Strategi W-T untuk usaha tempura ikan Perusahaan x adalah:

a) Membuat kemasan yang lebih menarik dari produk lainnya dan memberikan pelatihan kerja bagi karyawan

Membuat kemasan semanarik mungkin dengan melihat warna produk yang membuat konsumen tertarik ketika melihat pertama kali, memberikan label halal, tanggal kadaluwarsa, dan aroma ikan tenggiri yang tidak begitu menyengat. Produk dengan kemasan yang menarik dapat menjadi pendorong bagi pembeli untuk membelinya, karena tidak jarang keputusan untuk membeli suatu produk terjadi hanya karena terpengaruh oleh bungkus yang menarik.

b) Melakukan kerjasama dengan pihak pemasok

Menjalin kerjasama antar pihak pemasok ikan tenggiri. Karena ini sangat penting apabila pemasok terlambat mengirimkan bahan baku yang dibutuhkan untuk proses produksi maka produksi menjadi terhambat dan permintaan konsumen tidak terpenuhi dan mengakibatkan loyalitas konsumen akan menjadi hilang terhadap produk tersebut. Untuk menghindari keterlambatan dalam pengiriman bahan baku, kedua belah pihak harus bekerja sama sesuai dengan kesepakatan yang telah disepakati. Hasil perumusan strategi oleh para pakar pada analisis matriks SWOT dapat dilihat pada Tabel 5.

Alternatif strategi yang dihasilkan dimasukkan ke dalam strategi yang telah dirumuskan pada matriks IE yaitu tumbuh dan kembangkan, yaitu:

\section{Strategi Penetrasi Pasar}

Srategi ini merupakan suatu strategi pertumbuhan di mana perusahaan berfokus pada penjualan produkproduk yang ada di pasar-pasar yang telah ada sebelumnya. Dan juga Meningkatkan harga dan kualitas produk, melakukan promosi dan sosialisasi kepada masyarakat tentang manfaat gizi ikan sebagai kesehatan bagi tubuh manusia.

\section{Strategi Pengembangan Pasar}

Strategi ini merupakan strategi pertumbuhan, di mana unit bisnis berusaha untuk menjual produk-produk yang telah ada di pasar-pasar yang baru dengan memperluas outlet-outlet Tempura Ikan, dan menjualkan produk ke restoran kecil, katin sekolah, dan juga warung makanan.

\section{Strategi Pengembangan Poduk}

Strategi ini merupakan strategi pertumbuhan di mana sebuah unit bisnis memperkenalkan produk baru ke pasar-pasar yang telah ada. Hal ini mungkin memerlukan strategi pengembangan kompetensi baru dan memerlukan program pemasaran yang baru pula untuk mengembangkan produk yang dapat diubah atau dikembangkan ke pasar yang telah ada dengan membuat kemasan Tempura Ikan lebih menarik dari produk lainnya dan memberikan keterampilan dalam mengolah produk tempura ikan yang menarik dan praktis. 
4. Strategi Integrasi ke belakang

Strategi integrasi ke belakang digunakan dengan memperoleh kepemilikan atau meningkatkan kendali atas perusahaan pemasok dengan melakukan kerjasama dengan pihak pemasok Tempura Ikan X.

Tabel 5. Hasil analisis matriks SWOT

\begin{tabular}{|c|c|c|}
\hline & $\begin{array}{ll}\text { Faktor Kekuatan/Strenght } \\
\text { (S) }\end{array}$ & 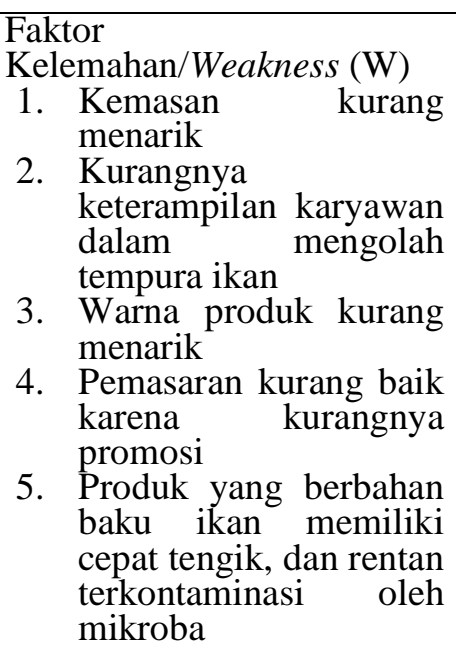 \\
\hline $\begin{array}{l}\text { Faktor } \\
\text { Peluang/Opportunities }(\mathrm{O}) \\
\text { 1. } \\
\text { Adanya promosi } \\
\text { pemerintah tentang } \\
\text { gerakan "ayo makan } \\
\text { ikan" sebagai sumber } \\
\text { protein } \\
\text { 2. Masyarakat mulai } \\
\begin{array}{l}\text { menyukai tempura } \\
\text { ikan }\end{array} \\
\text { 3. Himbauan camilan } \\
\text { 4ehat untuk anak-anak } \\
\text { 4. Kebutuhan konsumen } \\
\text { akan produk } \\
\text { fungsional, berbentuk } \\
\text { produk siap jadi } \\
\text { sehingga praktis }\end{array}$ & $\begin{array}{l}\text { Strategi SO } \\
\text { 1. Meningkatkan harga } \\
\text { dan kualitas produk } \\
\text { (S1, S2, S3, S4, S5, } \\
\text { O2, O3,O4,) } \\
\text { 2. Melakukan promosi } \\
\text { dan sosialisasi kepada } \\
\text { masyarakat secara } \\
\text { berkala tentang } \\
\text { maanfaat gizi ikan } \\
\text { sebagai kesehatan bagi } \\
\text { tubuh manusia (O1,O3, } \\
\text { S3, S4, S5) }\end{array}$ & \begin{tabular}{ll} 
& \multicolumn{1}{c}{ Strategi WO } \\
1. & Memperluas pasar \\
dengan cara & \\
menjualkan produk ke \\
restoran kecil, kantin \\
sekolah, dan juga \\
warung makanan $(\mathrm{O}, 2$, \\
O3, W4, O4) \\
2. \\
Melatih karyawan \\
dengan cara \\
memberikan pelatihan \\
keterampilan dalam \\
mengolah produk \\
tempura ikan yang \\
menarik dan praktis \\
(O4, W1, W2, W3, \\
W5)
\end{tabular} \\
\hline $\begin{array}{rlr}\text { ANCAMAN (T): } & \\
\text { 1. } & \text { Kompetitor atau } \\
& \text { pesaing } \\
& \text { menghasilkan produk } \\
& \text { yang sejenis } \\
\text { 2. } & \begin{array}{l}\text { Harga bahan baku yang } \\
\text { tidak stabil }\end{array}\end{array}$ & $\begin{array}{l}\text { Strategi ST } \\
\text { 1. Menjaga cita rasa } \\
\text { produk yang khas agar } \\
\text { tidak berubah dari } \\
\text { tahun ke tahun (S1,S3, } \\
\text { S5, T1) } \\
\text { 2. Melakukan } \\
\text { pengelolaan persediaan } \\
\text { bahan baku yang } \\
\text { efisien dan efektif (S2, } \\
\text { T2) }\end{array}$ & 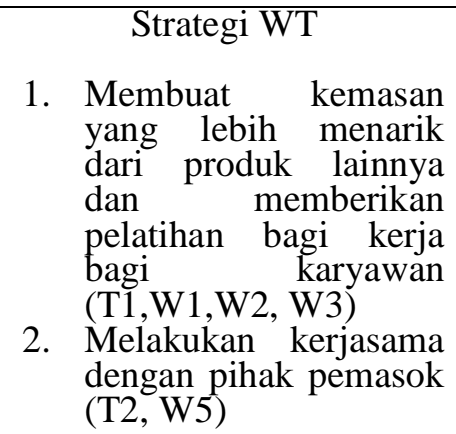 \\
\hline
\end{tabular}

\section{Tahap Keputusan (Decision Stage)}

Setelah diperoleh beberapa alternatif strategi melalui tahap pencocokan dengan menggunakan matriks IE dan matriks SWOT, maka tahap terakhir adalah tahap keputusan pemilihan strategi yang terbaik. Adapun alat yang digunakan pada tahap ini adalah dengan menggunakan metode TOPSIS (Technique for Order of Preference by Similarity to Ideal Solution) merupakan salah satu metode pengambilan keputusan multikriteria atau alternatif pilihan yang merupakan alternatif yang mempunyai jarak terkecil dari solusi ideal 
positif dan jarak terbesar dari solusi ideal negatif dari sudut pandang geometris dengan menggunakan jarak Euclidean. Alternatif penilaian dapat dilihat pada Tabel 6 dan kriteria dapat dilihat pada Tabel 7.

Tabel 6. Alternatif

\begin{tabular}{cl}
\hline Alternatif & \multicolumn{1}{c}{ Keterangan } \\
K1 & $\begin{array}{l}\text { Meningkatkan harga dan kualitas produk } \\
\text { K2 }\end{array}$ \\
K3 & $\begin{array}{l}\text { Melakukan promosi dan sosialisasi kepada masyarakat secara berkala tentang } \\
\text { Memperluas pasar dengan cara menjualkan produk ke restoran kecil, kantin sekolah, } \\
\text { dan juga warung makanan }\end{array}$ \\
K4 & $\begin{array}{l}\text { Melatih karyawan dengan cara memberikan pelatihan keterampilan dalam mengolah } \\
\text { produk tempura ikan yang menarik dan praktis }\end{array}$ \\
K5 & Menjaga cita rasa produk yang khas agar tidak berubah dari tahun ke tahun \\
K6 & $\begin{array}{l}\text { Melakukan pengelolaan persediaan bahan baku yang efisien dan efektif } \\
\text { Membuat kemasan yang lebih menarik dari produk lainnya dan memberikan } \\
\text { pelatihan bagi kerja bagi karyawan } \\
\text { Ke }\end{array}$ \\
K8 & Melakukan kerjasama dengan pihak pemasok \\
\hline
\end{tabular}

Tabel 7. Kriteria

\begin{tabular}{cc}
\hline Kriteria $\left(\mathbf{A}_{\mathbf{i}}\right)$ & Keterangan \\
\hline $\mathrm{A} 1$ & Kekuatan \\
$\mathrm{A} 2$ & Kelemahan \\
$\mathrm{A} 3$ & Peluang \\
$\mathrm{A} 4$ & Ancaman \\
\hline
\end{tabular}

Metode TOPSIS menghasilkan nilai preferensi yang dapat dilihat pada Tabel 14. Berdasarkan Tabel 14. Strategi yang memiliki nilai preferensi paling tinggi terdapat pada alternatif K3 dengan nilai 1,000. Dengan nilai preferensi 1,000 dapat disimpulkan bahwa dengan cara memperluas pasar dengan cara menjualkan produk ke restoran kecil, kantin sekolah, dan juga warung makanan. Produk merupakan salah satu unsur yang paling penting dalam sebuah pasar, karena dengan adanya produk maka akan terjadi pertukaran dan transaksi jual beli antar pelaku yaitu antara produsen dan konsumen. Untuk itu, dalam menghasilkan produk suatu perusahaan hendaknya sesuai dengan kebutuhan dan keinginan konsumen (Arief, 2014).

Alternatif strategi kedua yang terpilih adalah K2 dengan nilai 0,573, alternatif strategi terpilih ketiga yang terpilih adalah $\mathrm{K} 1$ dengan nilai 0,458, alternatif strategi keempat yang terpilih K5 dengan nilai 0,343, alternatif strategi kelima yang terpilih adalah K7 dengan nilai 0,295, alternatif strategi keenam yang terpilih adalah K6 dengan nilai 0,280, alternatif strategi ketujuh yang terpilih adalah K8 dengan nilai 0,087 dan alternative strategi kedelapan yang terpilih adalah K4 dengan nilai 0,000. 
Tabel 8. Nilai preferensi

\begin{tabular}{|c|c|c|c|}
\hline No & $\begin{array}{l}\text { Alternatif } \\
\text { Strategi }\end{array}$ & Keterangan & $\begin{array}{c}\text { Nilai } \\
\text { Preferensi }\end{array}$ \\
\hline 1. & K1 & Mempertahankan harga dan kualitas produk & 0,458 \\
\hline 2. & K2 & $\begin{array}{l}\text { Melakukan promosi dan sosialisasi kepada masyarakat secara } \\
\text { berkala tentang maanfaat gizi ikan sebagai kesehatan bagi } \\
\text { tubuh manusia }\end{array}$ & 0,573 \\
\hline 3. & K3 & $\begin{array}{l}\text { Memperluas pasar dengan cara menjualkan produk ke restoran } \\
\text { kecil, kantin sekolah, dan juga warung makanan }\end{array}$ & 1,000 \\
\hline 4. & K4 & $\begin{array}{l}\text { Melatih karyawan dengan cara memberikan pelatihan } \\
\text { keterampilan dalam mengolah produk tempura ikan yang } \\
\text { menarik dan praktis }\end{array}$ & 0,000 \\
\hline 5. & K5 & $\begin{array}{l}\text { Menjaga cita rasa produk yang khas agar tidak berubah dari } \\
\text { tahun ke tahun }\end{array}$ & 0,280 \\
\hline 6 & K6 & $\begin{array}{l}\text { Melakukan pengelolaan persediaan bahan baku yang efisien } \\
\text { dan efektif }\end{array}$ & \\
\hline 7. & K7 & $\begin{array}{l}\text { Membuat kemasan yang lebih menarik dari produk lainnya dan } \\
\text { memberikan pelatihan kerja bagi karyawan }\end{array}$ & 0,295 \\
\hline 8. & K8 & Melakukan kerjasama dengan pihak pemasok & 0,087 \\
\hline
\end{tabular}

\section{KESIMPULAN DAN SARAN}

\section{Kesimpulan}

1) Hasil penelitian untuk analisis faktor lingkungan internal produksi tempura ikan Perusahaan $X$ menunjukkan bahwa terdapat 5 faktor kekuatan dan 5 faktor kelemahan yang dimiliki tempura ikan Perusahaan X. Berdasarkan nilai analisis tempura ikan Perusahaan X berada pada posisi yang kuat dalam menghadapi segala kelemahan. Kekuatan utamanya adalah (1) bebas bahan pengawet (2) bahan baku ikan tenggiri memiliki cita rasa yang khas sedangkan kelemahan utamanya pada produk adalah kemasan kurang menarik dan keterampilan karyawan dalam mengolah tempura ikan. Berdasarkan analisis faktor lingkungan eksternal tempura ikan Perusahaan X memiliki 4 peluang dan 2 ancaman. Berdasarkan nilai analisis EFE tempura ikan Perusahaan $\mathrm{X}$ berada pada posisi kuat dalam mengatasi ancaman yang datang dari luar dengan cara memanfaatkan peluang. Peluang utamanya adalah adanya promosi pemerintah tentang gerakan "ayo makan ikan" sebagai sumber protein sedangkan ancaman utamanya adalah kompetitif atau pesaing yang menghasilkan produk yang sejenis.

2) Hasil yang didapat dari merumuskan strategi dan menerapkan prioritas strategi pengembangan usaha tempura ikan Perusahaan $\mathrm{X}$ adalah strategi tumbuh dan kembangkan yang terdiri dari strategi intensif (penetrasi pasar, pengembangan pasar, dan pengembangan produk) atau strategi integratif (integrasi ke belakang, integrasi ke depan, dan integrasi horizontal). Berdasarkan alternatif-alternatif dari matriks SWOT diperoleh 8 strategi untuk mengembangkan usaha tempura ikan Perusahaan X. Prioritas strategi berdasarkan metode TOPSIS adalah memperluas pasar dengan cara menjualkan produk ke restoran kecil, kantin sekolah, dan juga warung makanan

\section{Saran}

1) Memanfaatkan kekuatan dan peluang yang dimiliki tempura ikan Perusahaan $X$ untuk mengembangkan usaha dengan cara memperluas pasar dengan menjualkan produk ke restoran,warung dan kantin sekolah dan juga membuka outlet-outlet baru serta meningkatkan harga 
dan kualitas produk. Tempura Ikan yang berbahan baku utama ikan tenggiri yang memiliki kandungan protein yang tinggi baik untuk kesehatan tubuh bagi manusia. Selain itu, tempura ikan Perusahaan $\mathrm{X}$ juga harus memiliki kerjasama yang mengikat dengan pihak pemasok, membuat kemasan yang lebih menarik dan memberikan pelatihan keterampilan bagi karyawan.

2) Menerapkan strategi tumbuh dan kembangkan yaitu terdiri dari strategi intensif (penetrasi pasar, pengembangan pasar, dan pengembangan produk) atau integratif (integrasi ke belakang, integrasi ke depan, dan integrasi horizontal). Serta menerapkan prioritas strategi terpilih yaitu dengan memperluas pasar dengan cara menjualkan produk ke restoran kecil, kantin sekolah, dan juga warung makanan

\section{DAFTAR PUSTAKA}

Arief, R.K. 2014. Total Marketing. Yogyakarta. Kobis

David, F. R. 2009. Strategic management, 12th ed. New Jersey. Pearson Prentice Hall

Glueck, W. F. 1998. Manajemen Strategis dan Kebijakan Perusahaan. Penerbit Erlangga. Jakarta.

Hasan, A. 2010. Marketing dari Mulut ke Mulut Word Of Mouth Marketing. Yogyakarta. Media Presindo

Kotler, P. dan Amstrong. 1997. Dasar-Dasar Pemasaran jilid 1 dan 2. Jakarta.

Martosubroto, P., N, Naamin dan BBAA, Malik. 1991. Potensi Dan Penyebaran Sumber Daya Ikan Laut Di Perairan Indonesia. Ditjenkan Puslitbangkan Oseanologi.

Manulang, M. 2005. Dasar-Dasar Manajemen. Universitas Gadjah Mada. Yogyakarta. 